\title{
Perceptions of Crime Prevention Through Environmental Design (CPTED) at Australian Railway Stations
}

\author{
Paul Cozens \\ Curtin University \\ Tiffany van der Linde \\ Harley Dykstra Planning and Survey Solutions
}

\begin{abstract}
Personal safety and security are essential criteria for measuring the quality of public transport, and research has consistently demonstrated that crime and fear of crime affect levels of patronage. Although authorities throughout the world are implementing Crime Prevention Through Environmental Design (CPTED), research and practice commonly focus on the elements of surveillance, territoriality, and controlling access. Few studies have investigated the CPTED concepts of "image management" or "geographical juxtaposition" (the surrounding environment). This research compares and contrasts the perceptions of rail users and security experts in relation to two railway stations in Perth, Western Australia. One station was designed in accordance with CPTED principles, and one was not. Interestingly, the findings indicate that the rail users perceived the station that was not designed using CPTED to be marginally safer and to exhibit slightly higher levels of CPTED qualities. This exploratory investigation suggests that the effectiveness of CPTED is mediated by the local environment surrounding each station and its associated image.
\end{abstract}

\section{Introduction}

One of the essential criteria for measuring the quality of public transport is safety and security (Dragu, Roman, and Roman 2013). Although "crime on public transport is relatively rare" (Batley et al. 2014, 33), research has demonstrated consistently that crime and fear of crime can affect levels of patronage (Crime Concern 1997, 2002, 2004; Cozens et al. 2004; Delbosc and Currie 2012). Patronage levels could be more than $10 \%$ higher if people felt more secure when traveling and waiting at railway stations (Crime Concern 2002, 2004). 
Crime Prevention Through Environmental Design (CPTED) has been increasingly used to reduce crime on public transport and, in particular, in and around railway stations (Carr and Spring 1993; Loukaitou-Sideris and Banerjee 1994; Department of Transport and the Regions 1998a; Cozens 2003a, 2003b, 2004). However, most research and applications of CPTED have concentrated on Newman's (1973) concepts promoting surveillance and territoriality (e.g., La Vigne 1996, 1997; Department of Transport and the Regions 1998b; Cozens 2002, 2003a, 2003b, 2004) and in managing graffiti and vandalism (Sloan-Hewitt and Kelling 1997; Thompson et al. 2012).

This study explores the relatively under-researched CPTED elements of image and stigma and geographical juxtaposition in relation to two railway stations in Perth, Western Australia (WA). Furthermore, since the research indicates there are reported differences in the perceptions of "experts" and the general public (Groat 1982; Devlin 1990; Downing 1992; Purcell and Nasar 1992; Stamps and Nasar 1997), this research compares rail users' and security "experts" perceptions of crime, image management, geographical juxtaposition, and CPTED at two railway stations in WA. One of these stations was designed using CPTED and the other was not.

\section{Crime Prevention Through Environmental Design (CPTED)}

Perceptions of safety are influenced by many factors, including the built environment and the design of railway stations (Gilling 1997; Smith and Clarke 2000; Schmucki 2002; Cozens et al. 2002, 2003a, 2003b, 2004; Smith 2008; Sorensen, Hayes, and Atlas 2008; Vilalta 2011; Delbosc and Currie 2012). Thus, it follows that good environmental design may decrease crime and fear of crime. CPTED is now a relatively common approach used to reduce crime and the fear of crime in and around railway stations (La Vigne, 1996; 1997; Department of Transport and the Regions 1998b; Cozens 2002, 2003a, 2003b, 2004; Batley et al. 2012).

A recent review of the UKs Secured Station Scheme (SSS) reveals that reductions in crime (e.g., theft from the person, criminal damage, and vehicle crimes), higher levels of personal safety, and increases in patronage were associated with stations which were awarded SSS accreditation (Batley et al. 2014). This scheme was launched in 1998, and more than 1,250 stations have received accreditation (Batley et al. 2014) based on three criteria: (1) stations must achieve a specific ratio of crimes per passengers, (2) stations must achieve a high CPTED audit score, and (3) stations must demonstrate adequate management processes and low levels of passenger perceptions of crime (DETR 1998a, 1998b). Crucially, accreditation is for a two-year period, after which re-accreditation is necessary.

CPTED focuses on seven key concepts - territoriality, surveillance, image management, activity support, access control, target hardening, and geographical juxtaposition (see Figure 1). These ideas have been presented at length elsewhere (e.g., see Cozens et al. 2005; Ekblom 2011; Cozens 2014; Cozens and Love 2015) and are discussed briefly below. 
FIGURE 1.

CPTED and component concepts

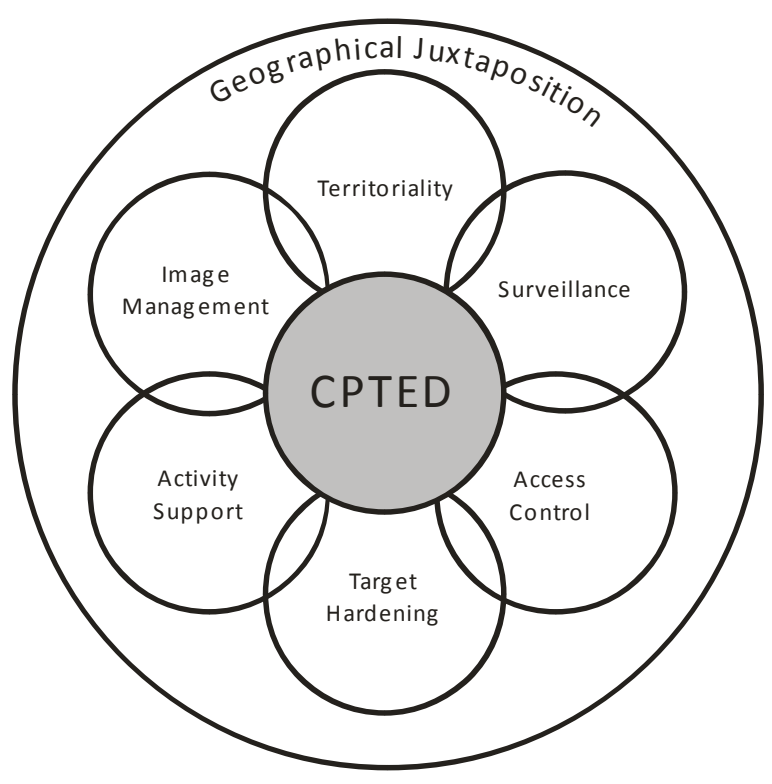

Source: Cozens 2014

Territoriality refers to designing spaces in a way that provides a sense of ownership and proprietary concern by residents/users so that they potentially are more likely to act as guardians. This might involve intervening in some way if they witness a crime (e.g., call the police) and includes the use of signage, fences, and barriers to define public and private spaces. Territoriality may alert offenders that certain behaviors are unacceptable and that criminality is more likely to be observed and reported (Sorensen, Hayes, and Atlas 2008).

Surveillance is about how design can enhance visibility, since most offenders do not want to be noticed. It can be promoted or hindered by environmental design and can influence crime and the perceptions of safety of those using such spaces (Newman 1973; Nasar and Fisher 1993; Schmucki 2002; Cozens et al. 2004; Moore 2010). The use of closed circuit television (CCTV) and security guards is another means of promoting the opportunities for surveillance, which can also help to reduce crime and the fear of crime (Ziegler 2007).

Access control is related to territoriality in that it helps define private and public space and controls who enters a specific site, building, or room and can include card entry systems, bollards, fencing, and walls (Cozens, Saville, and Hillier 2005; Sorensen, Hayes, and Atlas 2008).

Target hardening is a form of access control and focuses on making criminal activity more difficult by limiting opportunities for crime at the scale of the building (Ziegler 2007). It includes using stronger doors and windows and more efficient locks and alarms and seeks to harden targets by increasing the effort required to commit a crime (Gilling 1997; Sorensen, Hayes, and Atlas 2008). 
Image management is about creating an environment that looks like it is cared for and supervised. A clean and well-kept environment provides a sense of orderliness and control, which can nurture perceptions of safety as well as deter criminals (Wilson and Kelling 1982). Examples include the rapid removal of graffiti and the prompt repair of vandalism (Smith and Clarke 2000; Vilalta 2011).

Activity support involves attracting safe and legitimate activities into areas that are perceived as unsafe. This is achieved through the thoughtful design of urban spaces and the use of local events, functions, and other land uses to attract legitimate users. It is argued that with higher levels of "eyes on the street," criminals potentially are less likely to offend since they may have increased risks of being seen and potentially apprehended (Sorensen, Hayes, and Atlas 2008). Pedestrians also potentially may feel safer as a result.

Geographical juxtaposition refers to the influence that nearby land uses and activities may have on the safety and security of a particular site (Newman 1973). This particularly relates to land uses that have the tendency to generate crime, such as prisons, pubs, bottle shops (off-licenses), pharmacies, seedy hotels, vacant lots/buildings, and cash converters/pawn shops (Newton 2014). This also has been observed in relation to public transport with regard to bus stops (Loukaitou-Sideris 1999; Loukaitou-Sideris et al. 2001). However, it has been asserted that reference to the wider environment and geographical juxtaposition is lacking in the CPTED literature and, consequently, is rarely considered in the design of urban spaces (Cozens 2014). Therefore, it is likely that in addition to the CPTED principles outlined above, the wider environment plays a significant role in shaping perceptions of safety at railway stations (Cozens 2011, 2014). This also is supported by research in the field of environmental criminology, defined as "... the study of crime, criminality, and victimisation as they relate first, to particular places, and second, to the way that individuals and organisations shape their activities by place-based or spatial factors" (Bottoms and Wiles 1997, 305).

In Crime and Everyday Life, Felson and Boba (2010) highlight how different types of settings generate large amounts of crime. The riskiest settings include public routes (especially footpaths, parking facilities, and unsupervised transit areas), recreational settings (especially bars and some parks), public transport (especially stations and their vicinities), retail stores (especially for shoplifting), educational settings (especially at their edges), offices (especially when entered for theft), human support services (especially hospitals with 24-hour activities), and industrial locations (especially warehouses with "attractive" goods). Some of these types of land uses act as crime generators, crime attractors, or crime detractors (Brantingham and Brantingham 1993b, 1995, 1998, 2008). Crime generators are specific areas that attract large numbers of people for reasons unrelated to crime but provide criminal opportunities to offenders who may notice them. These include, for example, shopping centers and entertainment areas. Crime attractors are activity nodes that entice motivated offenders due to their known criminal opportunities for specific types of crime. Examples include entertainment districts, prostitution areas, and drug markets. Crime detractors are locations lacking attractive activities that discourage use by legitimate citizens (Brantingham and 
Brantingham 1995). Although such locations resonate with Newman's (1973) Defensible Space concept of geographical juxtaposition, it has been argued that the surrounding environment has not been subject to much research in the field of CPTED (Cozens 2014).

Indeed, Brantingham and Brantingham $(1998,53)$ argued "most planning proceeds with little knowledge of crime patterns, crime attractors, crime generators ... or the sitespecific solutions that facilitate or even encourage crime."

The concepts of image management and geographical juxtaposition are referred to by Newman (1973) in his book Defensible Space: People and Design in the Violent City. It is commonly recognized that modern CPTED is based on these ideas. The four elements of defensible space act together to help create and maintain a safer urban environment and include:

1. Capacity of the physical environment to create perceived zones of territorial influence.

2. Capacity of physical design to provide surveillance opportunities for residents and their agents.

3. Capacity of design to influence the perception of a project's uniqueness, isolation, and stigma.

4. Influence of geographical juxtaposition with "safe zones" on the security of adjacent areas (Newman 1973, 50).

Although "image management" emerged from Newman's third principle, and the rapid repair of vandalism and graffiti removal is a well-accepted CPTED strategy, research on image management also has been largely absent from the CPTED literature (Cozens 2014). This is particularly the case in relation to the research on railway stations, which has tended to concentrate on surveillance and territoriality/access control.

\section{Railway Station Study in Perth}

The Perth rail network is controlled by the Public Transport Authority (PTA), a government agency responsible for providing the train, bus, and ferry networks in WA. The Transperth division of the PTA is responsible for delivering these services within the Perth Metropolitan Region. Currently, there are five train lines, all of which converge at the Perth train station (see Figure 2)-Armadale, Midland, Fremantle, Mandurah, and Clarkson. In total, these lines service approximately 63 million passengers per year (Public Transport Authority 2014). 
FIGURE 2.

Perth's rail network showing Oats Street and Gosnells

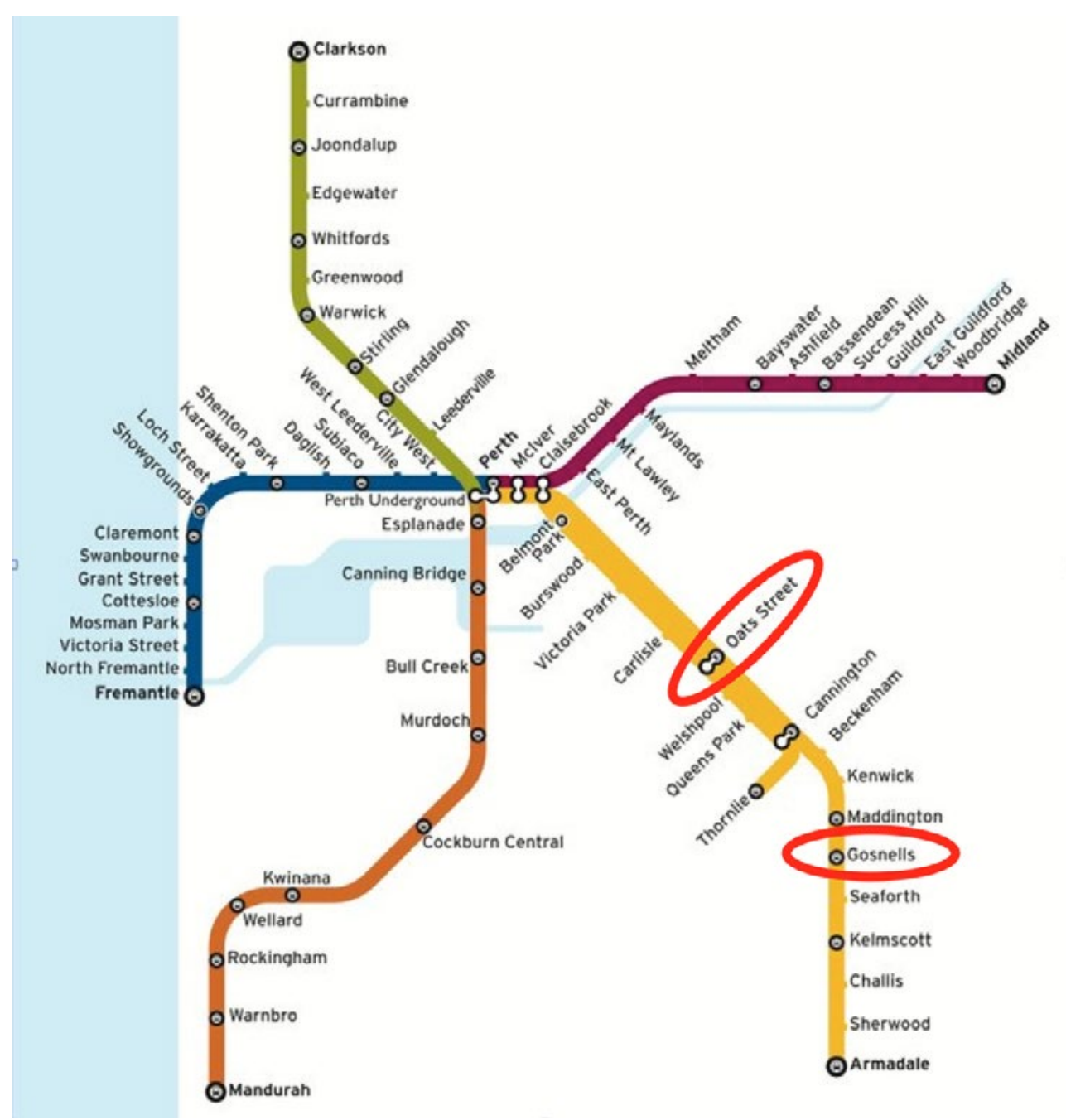

Source: $h$ ttp://www.mobilemaplets.com/thumbnails/8431_thumbnail-1024.jpg

In 2014, WA was named Australia's best rail network and was rated the safest in the country during daylight hours (Wahlquist 2014). Overall, crime is relatively low, with 40 incidents per million passengers recorded in 2013 (Wahlquist 2014). The Armadale line serviced around 9 million passengers in 2013/2014 (Public Transport Authority 2014) but is consistently associated with increased levels of crime (ABC News 2013). Indeed, a survey of 247 rail users on the Armadale line identified Oats Street as being the worst of five crime hotspots (Irons 2015). Interestingly, Gosnells station was not one of the five crime hotspots (Irons 2015).

Train stations along the Armadale train line were chosen due to an awareness of the negative reputation of this train line (Robertson 2012a, 2012b; Hickey 2013; Waters 2014a, 2014b). In terms of crime statistics and perceptions of crime, the Armadale line can be considered a "hot route" (Newton 2008; Thompson et al. 2009). 
The Gosnells and Oats Street train stations (see Figure 2) were selected for investigation due to their contrasting design characteristics and their similar reputations in the media, their relative proximal location to each other on the Armadale "hot route," and the fact that one was designed using the principles of CPTED and the other was not.

Importantly, Gosnells was designed as part of the Safe City Urban Design Strategy (City of Gosnells 2001). This strategy reportedly applied CPTED principles to the town center's urban structure and its local streets and surrounding land uses/residential areas. It was described by then WA Commissioner of Police Bob Falconer as "the best community safety strategy in Australia" (City of Gosnells 2001, 5).

The key characteristics of the Gosnels and Oats Street stations are shown in Table 1. A photograph of Gosnells station is shown in Figure 3 and an aerial image of its surrounding environment is shown in Figure 4. Oats Street station is illustrated in Figure 5 , and a location map of its surrounding environment is illustrated in Figure 6.

TABLE 1.

Comparison of Gosnells and Oats Street Stations: Key Characteristics

\begin{tabular}{|l|l|}
\hline \multicolumn{1}{|c|}{ Gosnells Station } & \multicolumn{1}{|c|}{ Oats Street Station } \\
\hline $\begin{array}{l}\text { Originally constructed in 1905, new station } \\
\text { platforms built in } 2005\end{array}$ & $\begin{array}{l}\text { Constructed in late 1990s as connecting node for } \\
\text { local buses }\end{array}$ \\
\hline $20.7 \mathrm{~km}$ south of Perth train station & $8.2 \mathrm{~km}$ south of Perth train station \\
\hline $\begin{array}{l}\text { Located along Armadale train line, services } \\
\text { southeastern corridor of Perth Metropolitan Area }\end{array}$ & $\begin{array}{l}\text { Located along Armadale train line, services } \\
\text { southeastern corridor of Perth Metropolitan Area }\end{array}$ \\
\hline $\begin{array}{l}\text { Services approximately 1,656 people per day } \\
\text { (Public Transport Authority 2014) }\end{array}$ & $\begin{array}{l}\text { Services approximately 2,885 people per day } \\
\text { (Public Transport Authority 2014) }\end{array}$ \\
\hline $\begin{array}{l}\text { Located west of town center approximately 100m } \\
\text { from major highway; bus interchange on west side } \\
\text { of station }\end{array}$ & $\begin{array}{l}\text { Bus interchange on east side of station, serviced by } \\
\text { two bus routes }\end{array}$ \\
\hline $\begin{array}{l}\text { Patrons include local people, shoppers, shop } \\
\text { workers, and people employed in local businesses }\end{array}$ & $\begin{array}{l}\text { Patrons include local people, large number of } \\
\text { students from local university }\end{array}$ \\
\hline Designed using CPTED principles & Designed without use of CPTED principles \\
\hline $\begin{array}{l}\text { Located near center of town among various } \\
\text { mixed-use retail and commercial developments }\end{array}$ & $\begin{array}{l}\text { More secluded location separated from town } \\
\text { center or retail and commercial land uses; } \\
\text { surrounded by residential properties and adjacent } \\
\text { to polytechnic }\end{array}$ \\
\hline
\end{tabular}

FIGURE 3. Gosnells train station

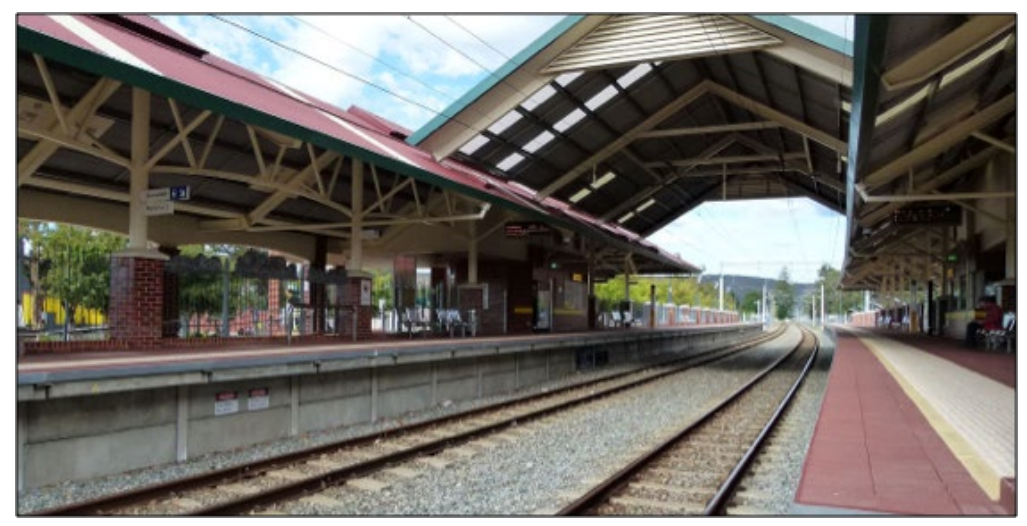

Source: Google Maps 2014 
FIGURE 4.

Aerial photograph of Gosnells

train station

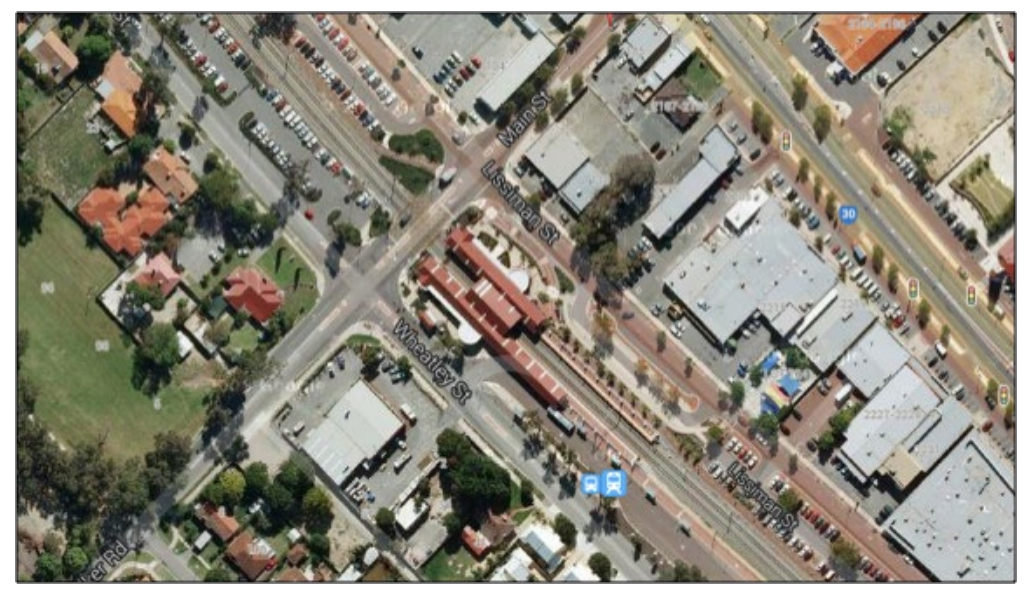

FIGURE 5.

Oats Street train station

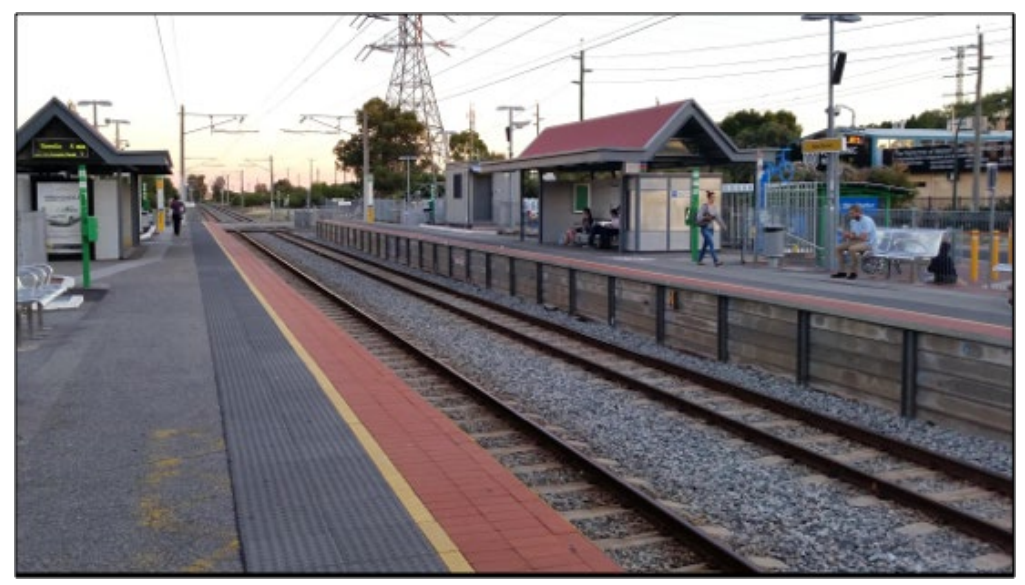

Source: Google Maps 2014

FIGURE 6.

Aerial photograph of Oats

Street train station showing

surrounding land uses

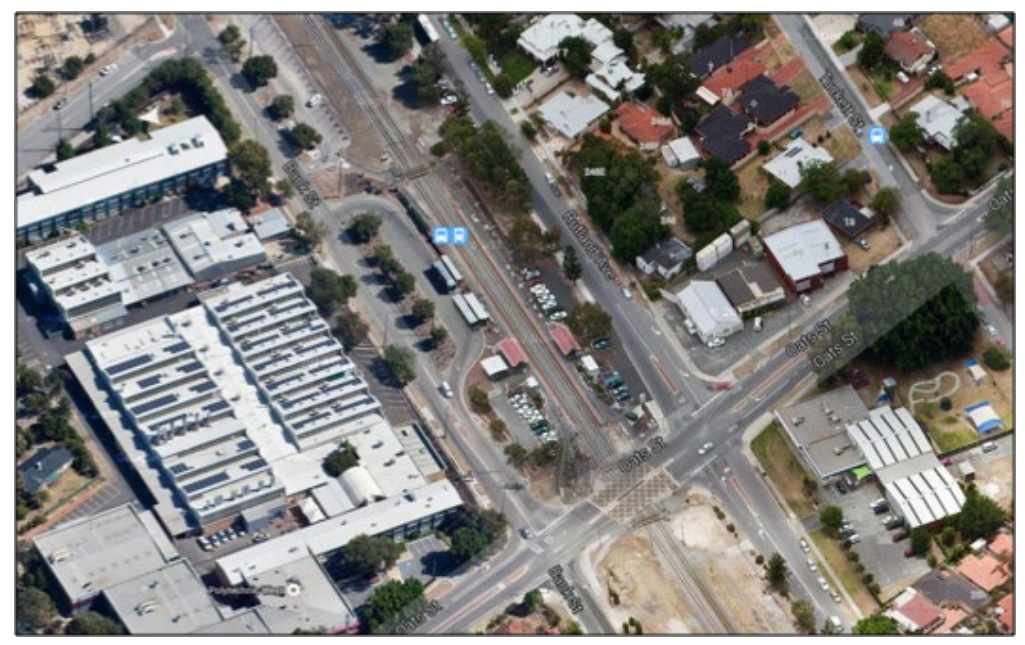


According to the literature, perceptions of safety and the presence of CPTED features at Gosnells station should be perceived to be higher than that of Oats Street station. This research investigates this hypothesis. It also probes the CPTED/Defensible Space concepts of "image management" and "geographical juxtaposition."

\section{Research Methodology}

This study adopted three methodologies, all conducted during September and October 2014. First, five public transport security experts were interviewed about crime and the CPTED strategies used (or not) at each station.

Second, 100 intercept survey questionnaires were conducted (50 each at Gosnells and Oats Street stations). Quota sampling ensured that responses maintained a gender balance and representation across all age groups. Drawing on the literature, the questionnaires probed three key areas. Two questions were directed at eliciting data on perceptions of safety while at the station and when entering/exiting the station. Four questions investigated respondents' perceptions of the presence or absence of CPTED qualities, including visibility at the station, surveillance from passers-by and surrounding land uses, CCTV, and security guards and exit points. Finally, two questions probed respondents' perceptions of the image and reputation of the stations and whether this would deter them from using the station. Binary yes/no responses to these questions were scored and are discussed below. This approach has been used elsewhere (e.g., see Cozens et al. 2003a, 2003b, 2004). The authors recognize that there are limitations to this exploratory research in that caution should be applied in drawing any conclusions from a relatively low sample size of 100 respondents.

The third methodology involved conducting a basic audit of the land-uses surrounding the Gosnells and Oat Street stations. This was to provide some insights in the local context and the influence of "geographical juxtaposition" on perceived safety, "image management," and the CPTED qualities at the two stations.

According to CPTED theory, Gosnells station should produce higher levels of perceived safety and CPTED qualities since it was reportedly designed using CPTED principles. The station user questionnaires adopted a simple quantitative method, and the interviews used a qualitative method, facilitating a more comprehensive meaning and comparison of the results (Sogunro 2002). These also could be contrasted with the land use survey to further explore the potential influence of the "geographical juxtaposition."

\section{Research Findings}

\section{Interviews with "Expert" Security Staff}

Five security staff were interviewed to investigate their "expert" opinions on crime and safety at the two train stations. When asked if they thought CPTED principles were applied to the Gosnells and Oats Street stations, all PTA interviewees confirmed that Gosnells station had been designed with CPTED principles and that Oats Street was not $(n=5)$. Respondents believed that Gosnells station was well-designed $(n=3)$ and that lighting and vegetation were particularly considered to be of a high standard at Gosnells station. 
However, it was also noted that despite the use of CPTED principles at Gosnells station, surrounding land uses did not produce a lot of activity to provide passive surveillance of the station $(n=2)$. The land uses are in private ownership and, thus, the owners need to be convinced to work together to develop the precinct as an activity node $(n=2)$.

It was reported by one PTA officer, who had completed tertiary studies in CPTED, that all new train stations in WA must use CPTED principles and architect designs must be approved. Both Gosnells and Oats Street stations are fitted with emergency panic buttons and public address (PA) systems that have direct contact with the PTA's control monitoring room, which is manned 24 hours per day, 7 days per week $(n=2)$. As soon as the emergency button is pressed, the closest CCTV camera zooms in on the location, and the person is able to voice their distress to the control room.

The Armadale line has been referred to as the "crime line." However, PTA respondents indicated that the reputation is undeserved and is linked to "out-of-context media reporting" and the socio-demographics of the surrounding suburbs $(n=3)$. There was some awareness that issues on the trains reflect those of the broader community.

Although one PTA officer believed the design of Gosnells station was effective in increasing perceptions of safety, he suggested that construction of a new station was required at Oats Street. In terms of the existing station at Oats Street, two officers felt that it was necessary to upgrade the shelters, cut down the vegetation, eliminate the level crossing, and provide more cameras, lighting, and monitored entry points to increase perceptions of safety.

Clearly, the "expert group" of PTA security staff believed that Gosnells station was designed more effectively than Oats Street, since CPTED principles had been systematically considered and applied to its design and layout.

\section{Rail Users' Perceptions}

As noted, the relatively small sample size of 100 survey respondents indicates that the findings are exploratory rather than definitive. Further studies or more surveys would need to be conducted to corroborate the findings discussed below. This section discusses rail users' responses to the eight questions in the survey, as set out in Tables 2,3 , and 4. Respondents could answer "strongly disagree," "disagree," "no preference," "agree" and "strongly agree." The number of responses out of 50 was recorded and expressed as a percentage score. Interestingly, overall, Table 2 indicates that respondents felt marginally safer at Oats Street station than they did at Gosnells station.

Perceptions of Safety at Gosnells and Oats Street Stations

\begin{tabular}{|l|c|c|c|c|}
\hline \multicolumn{1}{|c|}{ Perceptions of Safety } & \multicolumn{3}{c|}{ Gosnells } & \multicolumn{2}{c|}{ Oats Street } \\
\hline & 150 & $\%$ & 150 & $\%$ \\
\hline I feel safe at this station. & 33 & 66 & 39 & 78 \\
\hline I feel safe entering and exiting the station during the day. & 47 & 94 & 49 & 98 \\
\hline Total Personal Safety Score (out of 100 and as a \%) & 80 & $80 \%$ & 88 & $88 \%$ \\
\hline
\end{tabular}


For Gosnells station, most of the 50 respondents $(66 \%, n=33)$ agreed/strongly agreed with the statement "I feel safe at this station," and 22\% ( $n=11)$ stated that they disagreed/strongly disagreed. At Oats Street station, the majority of respondents (78\%, $\mathrm{n}=39$ ) indicated that they generally felt safe at the station. For Gosnells, the majority of rail users $(94 \%, n=47)$ agreed/strongly agreed they felt safe entering and exiting the station during the day, with slightly more responding similarly for Oats Street station $(98 \%, n=49)$.

Respondents also were asked four questions about the perceived CPTED qualities at each station (Table 3).

TABLE 3.

Perceived CPTED Qualities at Gosnells and Oats Street Stations

\begin{tabular}{|l|c|c|c|c|}
\hline \multicolumn{1}{|c|}{ CPTED Qualities } & \multicolumn{2}{c|}{ Gosnells } & \multicolumn{2}{c|}{ Oats Street } \\
\hline The station is designed to be open and visible and I feel safe. & 150 & $\%$ & $\mathbf{1 5 0}$ & $\%$ \\
\hline $\begin{array}{l}\text { The design of the station allows for surveillance from passers-by and } \\
\text { neighbouring land uses. }\end{array}$ & 40 & 80 & 45 & 90 \\
\hline There is sufficient surveillance from transit staff and CCTV. & 52 & 35 & 70 \\
\hline There are sufficient exits to ensure my safety. & 23 & 46 & 28 & 56 \\
\hline Total CPTED score (out of 200 and as a \%) & 37 & 74 & 43 & 86 \\
\hline
\end{tabular}

At Gosnells, the majority of respondents $(80 \%, n=40)$ agreed/strongly agreed that the design of the station was open and visible and made them feel safe, compared to a slightly higher $90 \%(n=45)$ of respondents at Oats Street.

At Gosnells, most respondents $(52 \%, \mathrm{n}=26)$ agreed/strongly agreed that passers-by and neighboring land uses could easily see into the station, and 34\% ( $n=17)$ disagreed/ strongly disagreed. Most of those argued that the station was in a "dead spot" situated behind shops and other land uses and was fronted by high asbestos fences. At Oats street, the majority of respondents $(70 \%, \mathrm{n}=35)$ stated that they agreed/strongly agreed with the statement, and $20 \%(n=10)$ of respondents disagreed/strongly disagreed. Some commented that there was minimal activity around the station and that neighborhood land uses were inactive after normal business hours. When asked about the presence of transit guards and security cameras, fewer than half $(46 \%, n=23)$ at Gosnells station and more than half $(56 \%, n=28)$ at Oats Street agreed/strongly agreed that such surveillance was sufficient.

Although the majority of respondents $(74 \%, n=37)$ agreed/strongly agreed that there were enough exits at Gosnells station to ensure their safety, many of the $22 \%(n=11)$ who disagreed/strongly disagreed noted that there is only one exit on each side from Gosnells station, providing no alternative to anyone who may feel threatened on the platform. When asked if there were enough exits to exit safely from Oats Street station, most $(86 \%, n=43)$ agreed/strongly agreed.

Overall, Table 3 indicates that the respondents perceived Oats Street to exhibit marginally higher levels of CPTED qualities (with a CPTED score of 76\%) than Gosnells, which received a CPTED score of $63 \%$. 
When asked about the reputation of the station, a minority $(16 \%, n=8)$ of respondents at Gosnells station agreed/strongly agreed that the station had a good reputation, and a significant majority (64\%, $n=32$ ) disagreed/strongly disagreed (Table 4). The questionnaire also asked respondents why they felt this way. The most common responses were that people had heard from others about criminal offenses and antisocial behavior that had occurred at the station. Some had witnessed anti-social behavior themselves, and many believed that the whole area, particularly the suburb of Gosnells, had a bad reputation. There were also concerns over the types of people at the station, including drunks, people trying to start fights, and so-called "dodgy" people hanging around.

TABLE 4.

Image and Stigma Associated with Gosnells and Oats Street Stations

\begin{tabular}{|l|c|c|c|c|}
\hline \multicolumn{1}{|c|}{ CPTED Qualities } & \multicolumn{2}{|c|}{ Gosnells } & \multicolumn{2}{c|}{ Oats Street } \\
\hline \multicolumn{1}{|c|}{} & $/ 50$ & $\%$ & $\mathbf{1 5 0}$ & $\%$ \\
\hline This station has a good reputation. & 8 & 16 & 18 & 36 \\
\hline $\begin{array}{l}\text { The reputation of the station has an effect on my decision to use it at any } \\
\text { time. }\end{array}$ & 13 & 26 & 11 & 22 \\
\hline
\end{tabular}

At Oats Street, $36 \%(n=18)$ of respondents agreed/strongly agreed the station had a good reputation. However, this was more than twice the number of those who felt Gosnells station had a good reputation. The same number disagreed/strongly disagreed that the station had a good reputation $(36 \%, n=18)$, which was significantly lower than for Gosnells station. Reasons for disagreeing included rumors of antisocial behavior, and some respondents had witnessed fights, assaults, and drunks at the station. Some also noted the negative media reports about Oats Street station as well as the generally poor reputation of the Armadale Train Line.

The majority of the 18 respondents who agreed/strongly agreed that Oats Street station has a good reputation stated that they had never seen or heard about any criminal or inappropriate behavior. Some stated that the station seemed safe and that there were always people around, which made them feel safer. Some who disagreed noted that they had no other method of transport and, thus, no choice about whether or not to use the station. Many who agreed with the statement stated that the reputation of the station resulted in them avoiding taking the train after dark if possible.

Respondents were asked if the reputation affected their decision to use the station. At both Gosnells ( $26 \%, n=13)$ and Oats Street $(22 \%, n=11)$, around one-fourth indicated that the poor reputation affected their use of the station. This raises the possibility that some of the respondents were "captive riders"- those who had no other travel options available to them and, therefore, must use the railway stations to travel.

As shown in Table 4, overall, rail users surveyed felt that CPTED principles at Oats Street station were marginally more effective in making them feel safer than at Gosnells station. This is in contrast to what would be expected, since Gosnells station was allegedly designed using the principles of CPTED and Oats Street station was not. At Oats Street station, $78 \%(n=39)$ of respondents agreed/strongly agreed that they felt 
safe. This was marginally more than the number of respondents at Gosnells, in which $66 \%(n=33)$ agreed/strongly agreed.

In summary, respondents felt safer at Oats Street station than at Gosnells. They also felt that Oats Street exhibited higher levels of CPTED qualities and has a better reputation than Gosnells station.

\section{Land Use Audit of Surrounding Environment}

An audit of land-uses around each railway station was conducted to provide an indication of the local context of each station and to probe the issue of "geographical juxtaposition." All land uses were recorded within a 200-meter radius of each station and were divided into various groups, including residential, retail/commercial, open space, educational settings, car parking, vacant lots/buildings, and roads/railway lines. Table 5 shows the estimated percentage of space each type of land use represents for both railways stations.

TABLE 5.

\begin{tabular}{|l|c|c|}
\hline \multicolumn{1}{|c|}{ Land Uses within $\mathbf{2 0 0 m}$ Radius } & $\begin{array}{c}\text { Gosnells Station } \\
\text { \% of Total Land Use Area }\end{array}$ & $\begin{array}{c}\text { Oats Street Station } \\
\text { \% of Total Land Use Area }\end{array}$ \\
\hline Residential & 10 & 45 \\
\hline Retail/commercial & 40 & 10 \\
\hline Open space & 10 & 5 \\
\hline Educational settings & 0 & 20 \\
\hline Car parking & 20 & 5 \\
\hline Vacant lots/buildings & 5 & 0 \\
\hline Roads/railway lines & 15 & 15 \\
\hline
\end{tabular}

Gosnells is located in an environment dominated by retail/commercial land uses, including a variety of restaurants (some take-away), several "big box" shopping centers, retail shops, a car repair business, and health-related stores. There is a range of local government services and psychological counseling services and several employment/ life skills services, as well as two large car parks, one northwest and one southeast of the station. The audit also identified several vacant lots/buildings, and a sizeable park is located east of the station.

Gosnells station is in close proximity to several land uses likely to generate or attract criminal behavior, such as the Gosnells Hotel (a licensed public house), a Totaliser Agency Board (TAB) betting/gambling establishment, several pharmacies, cash converters (pawn shops), massage parlors, vacant buildings/lots, and Centrelink, the unemployment office. As discussed earlier, evidence from environmental criminology suggests such land uses may act as crime attractors or crime generators. In any case, they appear to affect perceptions of crime and the perceived effectiveness of CPTED in and around the station. It is possible that the activity generated from these land uses may have negatively influenced perceived safety at Gosnells station. Users of Oats Street were more likely to be University students/staff, and those using Gosnells station were likely to derive from a more diverse population of shoppers, local workers, and people 
seeking to claim unemployment benefit from the surrounding suburbs. This also may impact perceptions of personal safety.

In contrast, Oats Street station is located within a predominantly residential environment, and the eastern side of the station directly faces a residential street. The polytechnic of West Carlisle is opposite the station on the west side, which is also surrounded by residential properties. The station has a small car park, and the railway line is flanked on both sides by two roads. There also is some retail, a bookstore, a gallery, a power station, a childcare centre to the south, and a small area of open space and a car park behind the polytechnic. The land uses surrounding Oats Street station does not appear to represent crime attractors or crime generators.

Geographically-juxtaposed land uses and activities may well be as important as the other CPTED concepts of surveillance, territoriality, and image management. Although more empirical studies are required, these preliminary findings suggest the surrounding environment acts to mediate the effectiveness of CPTED. For example, it would be interesting to compare two other stations with characteristics similar to Oats Street and Gosnells stations that are not on "hot" lines.

\section{Discussion and Conclusions}

The exploratory findings from this relatively small study raise some interesting issues. In summary, the five security "experts" believed Gosnells was the safest station since it was designed using CPTED principles. The literature suggests this station should be perceived to be safer than Oats Street, which was not designed using CPTED principles. However, this was not the case. The station users perceived Oats Street to exhibit marginally higher levels of CPTED qualities and felt it was slightly safer than Gosnells. These findings could, of course, be explained partly by the relatively small sample size or the fact that Gosnells station is perceived to be located in a dangerous area compared to Oats Street station. Another possibility is that CPTED was not implemented as effectively as it could have been.

The station users also felt that the reputation of Oats Street was more positive than Gosnells, although both stations were perceived to be somewhat stigmatized. This might be linked to the idea that the Armadale line is the "crime line." The land use survey provided some insights into the concept of "geographical juxtaposition," highlighting that crime generators and crime attractors around the Gosnells station may affect perceptions of the personal safety and the effectiveness of CPTED at the station itself. These preliminary findings suggest that CPTED surveys need to include some kind of measurement of geographically-juxtaposed land uses around the station. This was, after all, Newman's fourth Defensible Space principle (1973). More detailed research on land uses surrounding sites at which CPTED has been implemented may shed more light on this topic.

It is suggested that some form of CPTED survey or personal safety mapping of station users could become a more systematic and regular component of customer satisfaction surveys. This could then be used to redirect and target CPTED funding at specific 
stations. This also might be used to alter the number and location of CCTV cameras and/or the number of security staff.

That Gosnells station was developed in 2001 and one of the PTA's security experts completed tertiary studies in CPTED raises the issue of the effectiveness of CPTED at the station and the knowledge-base of the PTA security experts. Since 2001, there have been many significant developments in research in the field of CPTED, which are not necessarily formally taught within any tertiary studies (e.g., see Ekblom 2011; Cozens 2014; Cozens and Love 2015). Moreover, it has been argued that built environment and security professionals need to know much more about crime patterns and environmental criminology as a foundation for underpinning the use of CPTED (Brantingham and Brantingham 1998; Cozens 2011, 2014). Furthermore, although the station may have met the CPTED principles of the time, 14 years on, it appears that the station users in this exploratory study did not perceive there were high levels of CPTED qualities at Gosnells station. One conclusion from this preliminary study is that stations may need to be more regularly reviewed. Since CPTED is a process and not a design outcome (Crowe 2000; Cozens 2011, 2014), review arguably should take place on a more routine basis. Indeed, the UK's Secured Station Scheme requires stations to be re-accredited every two years.

CPTED is considered to be "best practice" and represents a large investment of public/ private funds. This exploratory study does not in any way suggest that CPTED does not work or is not a worthwhile investment for transportation agencies. Rather, it suggests that CPTED could be applied better by considering Newman's fourth and often forgotten Defensible Space principle of "geographical juxtaposition." Indeed, understanding the context and nature of the local environment may help explain the negative reputation of Gosnells station and its attempts to respond in terms of the redesign of the station using CPTED principles. It may well be the case that the CPTED design efforts simply were not enough to overcome the highly negative and stigmatized reputation of the area.

\section{References}

ABC News. 2013. "Armadale Tops List for Assaults on Public Train Lines in Perth." http:// www.abc.net.au/news/2013-06-21/armadale-tops-list-for-assaults-on-public-trainlines-in-perth/4770230, June 21. Accessed June 21, 2015.

Batley, R., M. Rogerson, J. Nellthorp, M. Wardman, A. Hirschfield, A. Newton, J. Shires, L. Monchuk, R. Armitage, K. Sharratt, D. Johnson, and P. Chintakayala, P. 2012. "Evaluating Measures to Improve Personal Security and the Value of Their Benefits." Project report, Rail Safety and Standards Board, http://eprints.hud.ac.uk/14650/. Accessed June 9, 2015.

Bottoms, A., and P. Wiles. 1997. "Environmental Criminology." In Maguire, M., R. Morgan, and R. Reiner (eds.), The Oxford Handbook of Criminology. Oxford, Clarendon Press: 305-359, 
Brantingham, P. J., and P. L. Brantingham. 1998. "Environmental Criminology: From Theory to Urban Planning Practice." Studies on Crime and Crime Prevention, 7(1): 3-60.

Brantingham, P., and P. Brantingham. 1993. “Nodes, Paths and Edges: Considerations on the Complexity of Crime and the Physical Environment." Journal of Environmental Psychology, 13: 3-28.

Brantingham, P. L., and P. J. Brantingham. 1995. "Criminality of Place: Crime Generators and Crime Attractors." European Journal of Criminal Policy and Research, 3: 5-26.

Brantingham, P., and P. Brantingham. 2008. "Crime Pattern Theory." In Wortley, R. and L. Mazerolle (eds), Environmental Criminology and Crime Analysis. Willan, Cullompton.

Brantingham, P. J., P. L. Brantingham, and P. S. Wong. 1991. "How Public Transit Feeds Private Crime: Notes on the Vancouver 'Skytrain' Experience." Security Journal, 2(2): 91-95.

Carr, K., and G. Spring. 1993. "Public Transport Safety: A Community Right and a Communal Responsibility." Crime Prevention Studies, 1: 147-155.

City of Gosnells. 2001. "Safe City Urban Design Strategy." City of Gosnells, Western Australia.

Cozens, P. M., R. H. Neale, J. Whitaker, and D. Hillier. 2003a. "Investigating Personal Safety at Railway Stations Using 'Virtual Reality' Technology." Facilities, 21(7/8): 188-193.

Cozens, P. M., R. H. Neale, J. Whitaker, and D. Hillier. 2003b. "Managing Crime and the Fear of Crime at Railway Stations-A Case Study in South Wales (UK)." International Journal of Transport Management, 1(3): 121-132.

Cozens, P. M. 2002. "Exploring Crime and the Fear of Crime within the Railway Environment." Public Transport International, 51: 20-24.

Cozens, P. M. 2011. “Urban Planning and Environmental Criminology: Towards a New perspective for Safer Cities." Planning Practice and Research, 26(4): 481-508.

Cozens, P., G. Saville, and D. Hillier. 2005. "Crime Prevention Through Environmental Design (CPTED): A Review and Modern Bibliography." Property Management, 23(5): 328-356. doi:10.1108/02637470510631483.

Cozens, P., R. Neale, J. Whitaker, and J. Hillier. 2004. "Tackling Crime and Fear of Crime While Waiting at Britain's Railway Stations." Journal of Public Transportation, 7(3): 23-41. http://www.nctr.usf.edu/jpt/pdf/JPT\% 207-3\%20Cozens.pdf.

Cozens, P. 2014. Think Crime! Using Evidence, Theory and Crime Prevention Through Environmental Design (CPTED) for Planning Safer Cities. Praxis Education, Quinn's Rock, Western Australia.

Crime Concern. 2002. "People Perceptions of Personal Security and Their Concerns about Crime on Public Transport: Literature Review." Department for Transport. 
Crime Concern. 2004. "People Perceptions of Personal Security and Their Concerns about Crime on Public Transport: Research Findings." Department for Transport.

Crime Concern and Transport and Travel Research. 1997. "Perceptions of Safety from Crime on Public Transport." Crime Concern and Transport and Travel Research for DETR.

Delbosc, A., and G. Currie. 2012. "Modelling the Causes and Impacts of Personal Safety Perceptions on Public Transport Ridership." Transport Policy, 24: 302-309. http:// dx.doi.org/10.1016/j.tranpol.2012.09.009.

DETR. 1998a. Personal Security on Public Transport. Guidelines for Operators. DETR Mobility Unit. Crown Copyright, London.

DETR. 1998b. Secure Stations Scheme. Guidelines for Operators. Crown Copyright, London.

Devlin, K. 1990. "An Examination of Architectural Interpretation: Architects versus NonArchitects." Journal of Architectural and Planning Research, 7: 235-244.

Downing, F. 1992. "Image Banks: Dialogues between the Past and Future." Environment and Behavior, 24: 441-470.

Dragu, V., E. Roman, and V. Roman. 2013. "Quality Assessment in Urban Public Transport." Theoretical and Empirical Research in Urban Management, 8 (3): 32-43. http://search.proquest.com.dbgw.lis.curtin.edu.au/docview/ 1460174044 ?accountid $=10382$.

Ekblom, P. 2011. "Deconstructing CPTED and Reconstructing It for Practice, Knowledge Management and Research." European Journal on Criminal Policy and Research, 17(1): 7-28.

Felson, M., and R. Boba. 2010. Crime and Everyday Life (4th Ed.). Sage Publications, Thousand Oaks, London, New Delhi.

Gilling, D. 1997. Crime Prevention: Theory, Policy and Politics. University College London, London.

Groat, L. 1982. "Meaning in Post-Modern Architecture: An Examination Using the Multiple Sorting Task." Journal of Environmental Psychology, 2: 3-22.

Hickey, P. 2013. "Teens, 14, 16, Charged over Oats Street Train Station Attack." The Australian, January 2. http://www.theaustralian.com.au/news/teens-chargedover-viciuys-oats-street-train-station-attack/story-e6frg6n6-1226546525436?nk= 7fc71e013f5b95c39eb022a28d7b7252.

Irons, S. 2015. "100\% of Survey Respondents Call for an Increased Transit Officer Presence." http://steveirons.com.au/local/news-hub/press-releases/100-surveyrespondents-call-increased-transit-officer-presence-irons/, January 8. Accessed June 21, 2015. 
La Vigne, N. G. 1996. "Safe Transport: Security by Design on the Washington Metro." In Clarke (ed.), Preventing Mass Transit Crime. Crime Prevention Studies, Volume 6: 163-198.

La Vigne, N. G. 1997. "Visibility and Vigilance: Metro's Situational Approach to Preventing Subway Crime." National Institute of Justice, Research in Brief, U.S. Department of Justice.

Loukaitou-Sideris, A. 1999. "Hot Spots of Bus Stop Crime: The Importance of Environmental Attributes." Journal of the American Planning Association, 65(4): 395411. Available at http://www.uctc.net/papers/384.pdf, abstract at http://www.uctc. net/papers/419.pdf.

Loukaitou-Sideris, A., and T. Banerjee. 1994. Form Follows Transit? The Blue-line Corridor's Development Potential. Department of Urban Planning, University of California, Los Angeles.

Loukaitou-Sideris, A., R. Liggett, and H. Iseki. 2001 "Measuring the Effects of Built Environment on Bus Stop Crime." Environment and Planning B: Planning and Design, 28: 255-280. Available at http://www.uctc.net/papers/419.pdf.

Moore, S. 2010. "Preventing Anti-Social Behaviour on Public Transport: An Alternative Route?" Crime Prevention and Community Safety, 12(3): 176-193. doi:10.1057/ cpcs.2010.9.

Nasar, J., and B. Fisher. 1993. “'Hot Spots' of Fear and Crime: A Multi-Method Investigation." Journal of Environmental Psychology, 13: 187-206. Available at http://www. sciencedirect.com.dbgw.lis.curtin.edu.au/science/article/pii/ S0272494405801732.

Newman, O. 1973. Defensible Space: People and Design in the Violent City. Architectural Press, London.

Newton, A. 2008. "Study of Bus Route Crime Risk in Urban Areas: The Changing Environs of a Bus Journey." Built Environment, 34(1): 88-103.

Newton, A. 2014. "Crime on Public Transport." In The Encyclopaedia of Criminology and Criminal Justice. Springer, London: 709-720.

Public Transport Authority. 2014. "Transperth Patronage." Government of Western Australia. http://www.pta.wa.gov.au/AboutUs/Overview/tabid/240/Default.aspx. Accessed June 19, 2015.

Purcell, A. T., and J. L. Nasar. 1992. "Experiencing Other People's Houses: A Model of Similarities and Differences in Environmental Experience." Journal of Environmental Psychology, 12: 199-212.

Robertson, K. 2012a. "Robbery Victim Hit over with Plank of Wood near Gosnells Train Station." Perth Now, November 16. http://www.perthnow.com.au/news/westernaustralia/robbery-victim-hit-over-with-plank-of-wood-near-gosnells-train-station/ story-e6frg13u-1226518020879. 
Robertson, K. 2012b. “Cowardly Thugs Attack Deaf Man at Oats Street Train Station.” Perth Now, June 12. http://www.perthnow.com.au/news/western-australia/cowardthugs-attack-deaf-man-at-oats-street-train-station/story-e6frg13u-1226392611692.

Schmucki, B. 2002. "On the Trams: Women, Men and Urban Public Transport in Germany." Journal of Transport History, 23(1): 60-72. Available at http://search. proquest.com.dbgw.lis.curtin.edu.au/docview/196617408?accountid=10382.

Sloan-Hewitt, M., and G. L. Kelling. 1997. 'Subway Graffiti in New York City: Gettin' up vs. Meanin' it and Cleanin' it." In Situational Crime Prevention: Successful Case Studies (2 ${ }^{\text {nd }}$ Edition). Clarke, R.V. (ed.). Harrow and Heston, New York: 242-282.

Smith, M. J. 2008. "Addressing the Security Needs of Women Passengers on Public Transport." Security Journal, 21: 117-133. doi:10.1057/palgrave.sj.8350071.

Smith, M. J., and R. V. Clarke. 2000."Crime and Public Transport." Crime and Justice 27: 169-233. http://www.jstor.org/stable/1147664.

Sogunro, O. A. 2002. "Selecting a Quantitative or Qualitative Research Methodology: An Experience." Educational Research Quarterl,y, 26 (1): 3-10. http://search. proquest. com.dbgw.lis.curtin.edu.au/docview/216183188/fulltextPDF/ C906BCB63CA4841PQ/6?accountid=10382.

Sorensen, S., J. Hayes, and R. Atlas. 2008. In 21 $1^{\text {st }}$ Century Security and CPTED: Designing for Critical Infrastructure Protection and Crime Prevention, Randall I. Atlas (ed.). Auerbach Publications, Boca Raton, FL: 53-78.

Stamps, A. E., and J. Nasar. 1997. "Design Review and Public Preferences: Effects of Geographical Location, Public Consensus, Sensation Seeking and Architectural Styles." Journal of Environmental Psychology, 17: 11-32.

Thompson, K., N. Offler, L. Hirsch, D. Every, M. Thomas, and D. Dawson, D. 2012. “From Broken Windows to a Renovated Research Agenda: A Review of the Literature on Vandalism and Graffiti in the Rail Industry." Transportation Research Part A, 46: 1280-1290. http://dx.doi.org/10.1016/j.tra.2012. 04.002.

Tompson, L., N. Partridge, and N. Shepherd. 2009. "Hot Routes: Developing a New Technique for the Spataila Analysis of Crime." Crime Mapping: A Journal of Research and Practice, 1(1): 77-96.

Vilalta, C. J. 2011. "Fear of Crime in Public Transport: Research in Mexico City." Crime Prevention and Community Safety, 13(3): 171-186. doi: 10.1057/cpcs.2011.4.

Wahlquist, C. 2014. "Survey Finds Only 28\% of People Feel Safe on Perth Trains at Night." Perth Now June 07. http://www.perthnow.com.au/news/western-australia/ survey-finds-only-28-per-cent-of-people-feel-safe-on-perth-trains-at-night/storyfnhocxo3-1226946616023, Accessed June 21, 2015.

Waters, S. 2014a. "Family Admits Station has Question Mark over Safety." The Comment News, July 15.

Waters, S. 2014b. “Armadale Line Patronage Down.” The Comment News, July 15. 
Wilson, J., and G. Kelling. 1982. "Broken Windows." Atlantic Monthly, 249(3): 29-38. http://www.manhattan-institute.org/pdf/_atlantic_monthly-broken_windows.pdf.

Ziegler, E. H. 2007. "American Cities, Urban Planning, and Place-Based Crime Prevention." The Urban Lawyer, 39(4): 859-875. http://search.proquest.com.dbgw.lis. curtin.edu.au/ docview/208559364?accountid=10382.

\section{About the Authors}

Paul Cozens, Ph.D. (p.cozens@curtin.edu.au), is a Senior Lecturer in the Department of Urban and Regional Planning at the School of Built Environment at Curtin University in Western Australia.

TIFFANY VAN DER LINDE (tiffany.vanderlinde@hotmail.com) is a Planning Consultant at Harley Dykstra Planning and Survey Solutions in Perth, Western Australia. 